\title{
eJRIEPS
}

Ejournal de la recherche sur l'intervention en éducation physique et sport

15 | 2008

Varia

\section{Creating and Sustaining Communities of Practice Among Physical Education Professionals}

\section{Mary O'Sullivan}

\section{(Q) OpenEdition \\ Journals}

Electronic version

URL: http://journals.openedition.org/ejrieps/5786

DOI: 10.4000/ejrieps.5786

ISSN: 2105-0821

\section{Publisher}

ELLIADD

\section{Electronic reference}

Mary O'Sullivan, "Creating and Sustaining Communities of Practice Among Physical Education

Professionals", eJRIEPS [Online], 15 | 2008, Online since 01 July 2008, connection on 02 May 2021.

URL: http://journals.openedition.org/ejrieps/5786 ; DOI: https://doi.org/10.4000/ejrieps.5786

\section{(c) (1)}

La revue eJRIEPS est mise à disposition selon les termes de la Creative Commons Attribution 4.0 International License. 
Mary O'Sullivan

Department of Physical Education and Sport Sciences

University of Limerick. Ireland

Résumé / abstract

Le concept de communauté de pratique a pris de l'importance dans les dernières années en tant que stratégie prometteuse pour la formation des maîtres. On peut aussi le considérer comme une façon de s'engager sur ce qui est sensible dans sa vie professionnelle. Les enseignants chargés de la formation des maîtres seraient plutôt d'avis que le but central de tout programme de formation serait de construire, chez les professeurs stagiaires, le fait que l'expertise en enseignement est un processus qui se développe tout au long de la vie. L'évolution de leur maîtrise et de leurs compétences à enseigner est en relation directe avec une bonne compréhension des curricula, un meilleur entendement des besoins des élèves et des changements dans les finalités de l'éducation dans la société contemporaine. Il y a une prise de conscience croissante que l'attention doit être portée sur la création et l'offre d'opportunités concernant le développement professionnel dans toute prévision de réforme éducative. Malheureusement, les programmes de formation professionnelle continue, dans beaucoup de pays, ont été supprimés ou considérés avec cynisme, comme quelque chose d'imposé plutôt que de fait avec eux. En bref, ce texte discute le développement de "communautés de pratique " pour tenter de résoudre ce problème.

The concept of a Communities of Practice has gained currency in recent years as a promising strategy to improve the quality of teacher education (Darling-Hammond \& Bransford, 2005). It is also viewed as way to engage teachers directly in directing the focus and delivery of professional development that is sensitive to their working lives (Craig, 2004; Little, 2002). Teacher educators would argue that a key goal of any teacher education programme is to instill among novice teachers the belief that teachers are life

\footnotetext{
1 This is a revision on a paper originally prepared for New Zealand Physical Education Association in April,
} 2007. 
long learners seeking to build their teaching and leadership capacities as they come to better understand their role in developing their curriculum, while attending to diverse students' needs, the demands of their content, and the changing purposes of education in contemporary society. There is increasing awareness that attention to the design and delivery of professional development initiatives for teachers should be a central tenet of any educational reform agenda. Unfortunately, professional development programming in many parts of the world have often been viewed with " a healthy cynicism" (Armour \& Yelling, 2004) as something done to teachers rather than with them. Teachers have been on the receiving end of state and educational directives rather than seen as key stakeholders and professionals who have a central understanding of what they need to improve the teaching and learning environments in which they work. Teachers are seeking professional development opportunities and they want these programmes to be contextually sensitive and supportive of their working conditions.

In this brief report I discuss an approach to professional development that revolves around the development of building and sustaining Communities of Practice. I discuss the benefits and challenges of this approach, and the underlying principles to be considered in developing Communities of Practice in relation to physical education. I draw examples from a Community of Practice developed in physical education and its potential usefulness for physical education teachers. First, we must contextualize the reasons for the increasing interest in new approaches to teacher professional development.

\section{Growing Interest in Professional Development}

The recent OECD Report (2005) Teachers Matters calls for greater attention to career and professional development (CPD) for teachers. The report noted that a lifelong learning perspective for teachers implies much more attention be focused on supporting teachers and providing incentives and resources for on-going professional development. The report noted there is better value to be gained by investing in professional development than in lengthening pre-service preparation.

The need for professional development of physical education teachers in particular has been highlighted in a number of recent reports including:

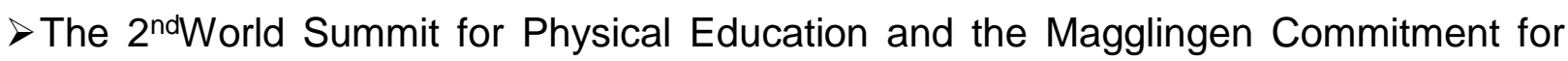
Physical Education called on all governments to invest in the continuing education of teachers of physical education (ICSSPE, 2005). 
$>$ There has been huge financical investment in career professional develoment (CPD) for physical education teachers in the UK with the Physical Education and School Sport and Community Links (PESSCL) Strategy (www.youthsporttrust.org).

$>$ There is also a growing government investement in professional development. One example is the VITAE project (Variations in Teachers Work, Lives, and Effectiveness) which highlighted the dynamic and emotional nature of professional life phases and recommended high quality professional development was central to supporting these aspects of teachers' lives (Day, 2006).

$>$ In a recent address to New Zealand teachers on realistic objectives for physical education in schools or on broader goals of a more active New Zealand Tinning (2000) highlighted the importance of the teacher in any curricular reform.

\section{Shifting Views of Professional Development}

The provision of professional development for PE teachers is not new. The most well known form of professional development is government supported in-service to make teachers aware of their responsibilities relative to a new or revised syllabus for physical education. Teachers are provided with one or more days of in-service training and some accompanying resources related to the syllabus and expected (usually without follow up support) to implement the syllabus in their local contexts. There is much to suggest this type of provision is expensive and less than effective in achieving its goals. Indeed there has been much criticism of these efforts as inadequate and not likely to increase teacher learning. (Armour \& Yelling, 2004; Guskey, 2002).

Governments are increasingly concerned about how well their investments in professional development are impacting student learning and teacher development. There are signs of a shift from the traditional focus on syllabus implementation and the transmission of the latest curriculum revisions to opportunities for teachers to dialogue about the values and relevance of various objectives and how the curriculum might align with local contexts. The University of Waikato researchers Alister Jones and Kirsten Petrie were funded to evaluate the impact of effective professional learning in curricular and co-curricular Physical Activity in Primary Schools. Their research highlighted the challenges in designing professional development that positively impacts teacher and student learning.

Chris Day's (1999) definition of professional development is helpful when thinking about new structures that provide teachers opportunities to learn: He noted that: 
It is the process by which, alone and with others, teachers review, renew and extend their commitment as change agents to the moral purposes of teaching;... and by which they acquire and develop critically the knowledge, skills and emotional intelligence essential to good professional thinking, planning and practice with children, young people and colleagues through each phase of their teaching lives (p. 4).

This view suggests professional development occurs in formal and informal settings and can occur in groups. Teachers are provided with opportunities to engage in dialogue and action with each other in addressing problems of practice and policy and in building their professional capacities and leadership skills in educating and motivating more young people to lead active and healthy lifestyles and to be critical consumers of sport and physical activity policies and practices.

\section{Community of Practice as Professional Development Initiative}

Situated learning theory is the theoretical framework underpinning the concept of a Community of Practice... The key premise is that learning is social and comes from our experiences on a daily basis (Lave \& Wenger, 1991). A Community of Practice defines itself in the doing, as members are involved in a set of relationships over time and work around things that matter to them. They develop among themselves their own understandings of what their practices and profession are about. A community of practice exists because it produces a shared practice as members engage in a collective process of learning. What I am suggesting here are places and spaces where physical education teachers have the opportunity to engage in worthwhile conversations and actions about the nature and direction of their work with children and youth. These are structured gatherings that allow for informal and formal learning to take place. The "conditions for improving teaching and learning are strengthened when teachers collectively question ineffective teaching routines, examine new conceptions of teaching and learning... and engage in actively in supporting professional growth" (Little 2002, p. 917). A community of practice's life cycle is determined by the value it provides to its members. Such high quality conversations and practices:

$>$ Include interactions among people where the participants audit the perspectives of others

> Participants learn to understand the historical locatedness of their practices (why are we doing what we are doing and what is gained from such efforts) 
> Build a set of practical theories of teaching and learning with teachers building their knowledge base as well as their leadership and mentoring capacities

$>$ Better able to anticipate future possibilities for their subject and the profession

\section{1. Benefits of Communities of Practices}

There is a growing body of literature promoting the values of collaborative professional learning communities. Teachers have much to teach each other. The structure of professional learning communities means coming together over time to interrogate their own teaching and work practices as well as the appropriateness of expectations for physical education and physical education teachers. My work with teachers over several years in building and sustaining a community of practice resulted in physical education teachers forming strong identities as teaching professionals. They were willing to reconsider their own practices to better enhance their students' experiences and to participate within their professional community for the betterment of their programme. They also developed a commitment to advocate for their subject at a wider policy level as well as refine their teaching role. They built (by working and sharing with others) capacities as instructional leaders, presenters and teachers, and created new images of themselves as teachers (Deglau \& O'Sullivan, 2006). When teachers collaborate in such communities they are more willing to take risks, reflect on their failures, and share successful programmes and practices (Craig, 2004; Deglau, Ward, \& O'Sullivan, 2006; Franke, Carpenter, Levi, \& Fennema, 2001).).

3. 2. Challenges of Communities of Practice

In the Irish and American educational contexts with which I have experience, I am under no illusion that such groupings are easy to create. They are even more difficult to sustain unless supported by the school principal and the educational system (i.e. Department of Education \& Science as in Ireland, or School Superintendent in the US educational system). Support can come in several forms but it usually includes time away from teaching to observe each other teach, share and learn new ideas, and spaces facilities to experiment with new curricular ideas (curriculum, teaching or assessment initiatives, applications of technology to teaching etc.). Etienne Wenger (1998), a scholar of learning theory describes how such groups develop, act out their brief, fade and reinvent themselves for a new challenge. Our challenge is to understand how to best facilitate Communities of Practice to help teachers in both the practical and intellectual work of teaching and ensure the ideas and values shared in the development of a physically educated citizenship are made real in the lives of their students. 
Wenger suggested five stages of development for Communities of Practice. We know very little about how professional development structures in education might support these stages. What I have done in this section is to adapt from Wenger's (1998) ideas how I think these structures might relate to creating Communities of Practice among physical education teachers. Teachers can't do this work alone but once created teachers must have increased ownership and leadership of these structures as their own leadership capacities develop and as their images of themselves as participants of such a community develops.

Potential Phase: Assist physical education teachers to find each other and discover their commonalities

Coalescing Phase: Explore connectedness, defining joint enterprise and negotiating how they will proceed with action

Active Phase: Engaging in activities, creating resources or other artefacts, developing commitment to task

Dispersed: $\quad$ Staying in touch, calling for advice, communicating

Memorable: No longer central but remembered as a significant part of their identities.

Having a shared professional concern or ambition can create a climate for the establishment of a learning community (e.g., new assessment challenges, growing levels of disinterest in traditional physical education offerings, learn new approaches to teaching specific aspects of the curriculum). There is need of a leader(s) who will arrange gatherings of teachers and funding to source these gatherings, to facilitate discussion on negotiating the collection mission of the group and ensuring that a climate of sharing and debating ideas is created within the group towards a shared purpose or task. The skills and knowledge of teachers in the group needs to be leveraged and somebody has to maintain focus on the task and ensure resources are created, opportunities built upon, and all need to ensure that their students are or will be enhanced by their collective and individual efforts. The community of practice will maintain itself if the experiences are deemed worthwhile, there efforts are recognized as worthwhile (by students, colleagues, principals), and there are new challenges to taken on board. Teachers helping other teachers and being supported and recognized for their efforts is a powerful and reaffirmation of their professionalism. 
Stages of Development

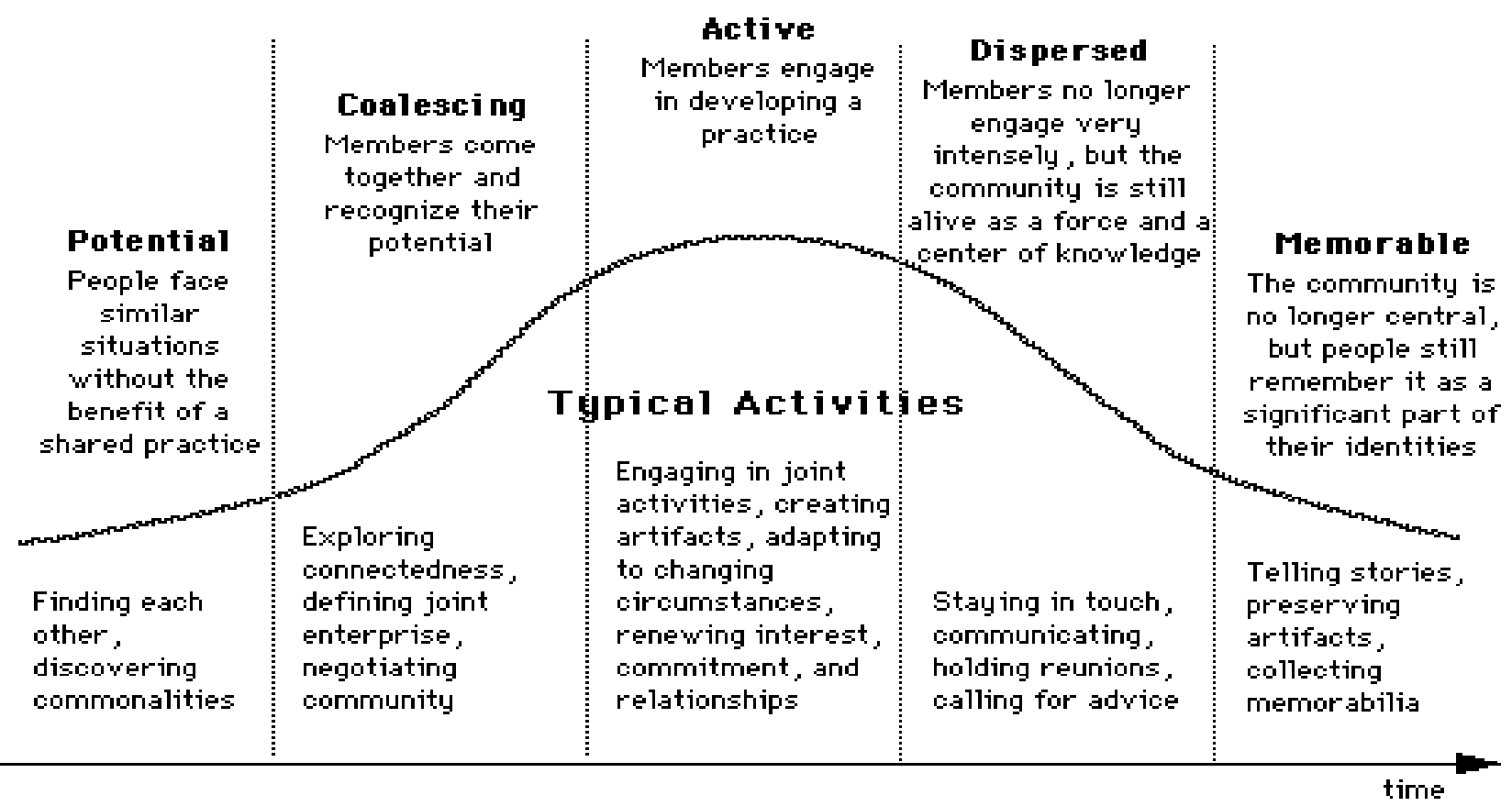

Figure 1. Stage of development.

Providing spaces for teachers to examine new ideas and to interrogate their own practices and experiences is central to teacher growth and development. Little (2002) noted that Conditions for improving teaching and learning are strengthened when teachers collectively question ineffective teaching routines, examine new conceptions of teaching and learning, find generative means to acknowledge and respond to difference and conflict and engage in actively in supporting professional growth (p. 917).

Getting this right is not easy and some of the tensions include:

- Balancing attention to content, teaching-learning process, assessment of learning, personal development of the teacher, and student learning?

- Providing practical relevance and intellectual stimulation

- Teachers wanting to know what rather than why

- Designing professional development experiences where teachers can admit deficits without being considered deficient

3. 3. Nurturing Communities of Practice

Communities of Practice must be nurtured. Some strategies include:

D Legitimate Participation. Creating an environment where the school, professional organization, parents, and community acknowledge the value of a Communities of Practice. This also requires that principals not only make it possible but also 
encourage involvement in such initiatives. These initiatives have to be local as ease of access is an important feature or sustained commitment.

Negotiating Strategic Context. Finding ways to use teacher knowledge and expertise for the benefit of the educational mission of the school. Recognizing teacher expertise and finding ways to leverage that expertise will enrich all and enhance teachers' commitment and resilience to enhanced student learning.

Fine Tuning the Organization. School systems (principals) need to adapt reward systems to support participation in learning communities

> Providing Support. Schools can support Communities of Practice by providing guidance and resources when needed and supporting their engagement in larger collaborative networks of physical education teachers and physical activity professionals.

These communities help teachers connect their physical education agenda to the larger school mission and encourages teachers to move forward with their agenda (with the support of teachers who have similar interests) yet remain focused on student learning. It also helps teachers create links to other communities, with outside expertise when appropriate. These kinds of groupings reflect the principles of High Quality Professional Development as summarized in a New Zealand document on Syntheses of Best Practices by Mitchell and Cubey (2003). Such Communities of Practice would:

$>$ Be focused on student learning

$>$ Involve teachers in identifying their own learning needs

$>$ Provide theoretical and content knowledge about alternative practices

$>$ Be school based and embedded in teachers' daily work lives

> Organized around collaborative problem solving using evidence from their own setting and comparing practice and learning expectations with relevant research

$>$ On going dialogue over time with on site support for teachers

Framework for CPD-PE: Communities of Practice

The findings of our recent research (Ward \& O'Sullivan, 2005), and the literature on high quality CPD suggests the modern teaching profession must sustain groups of physical education teachers as Communities of Learners. We must support:

A proactive, modern profession where teachers are seen as an important resource for each other in supporting and sustaining the development of their own and their colleagues' practice (Armour \& Makopoulou, 2005). 
$>$ Teachers must form and sustain professional development communities and school leaders must have the vision to see the value of such learning communities and the benefits of strong physical education programmers (Lave \& Wenger, 1991; Deglau \& O'Sullivan, 2006).

$>$ The evidence from our research with a Community of Practice in Columbus suggested that when teachers collaborate in such communities they are more willing to take risks, reflect on their failures, and share successful programmes and practices (Deglau \& O'Sullivan, 2006; Deglau, Ward, \& O'Sullivan, 2006).

$>$ We are now trying to replicate these efforts in Ireland, under the guidance of Deborah Tannehill at the University of Limerick. The Physical Education Association of Ireland (PEAI) received funding from the Irish Department of Education and Science to establish a series of physical education Communities of Practice. In 2006-2007 four such Communities of Practice began (see http://www.peai.org/ for details of the Irish context). . Tannehill and her colleagues (2006) are studying how teachers change their beliefs and practice as a result of participating in a community of practice $(\mathrm{CoP})$. The initial reports from this work suggest the CoP created several tensions among and between the teachers and their university colleagues. They have struggled to find ways to inspire deeper discussions among teachers that are focused more closely on their work and what is relevant to their lives as teachers. Such work requires time and investment by teachers as well as support from their principals The value of these structures needs further examination. .

Professional development for teachers is increasingly recognised as a vital component of policies to enhance the quality of teaching and learning in schools. Consequently, there is increased interest in research that identifies features of effective professional learning and these are some of the questions that need to be asked:

$>$ How are professional learning communities developed and who benefits from these structures?

$>$ How are professional learning communities (PLC) established at a scale that can truly have an impact on teaching environments; (leadership at the school level)?

> What impact can PLC have on the macro conditions that marginalize physical education in many schools? 


\section{Conclusion}

There is need for the support and nurturing of Communities of Practice among physical education teachers at local and regional levels and appropriate connections with other health and sport professsionals across organizations as needed. Teachers in these communities of practice must be supported and encouraged to share their expertise, organize and plan around common goals, generate a stronger voice to influence quality experiences for young people and impact on policies around active living. Such Communities of Practice have the potential to build teachers' capacities and teachers' imaginations and identities as professionals (Lave \& Wenger, 1991) in supporting high quality experiences in sport and physical activity for New Zealand's young people.

\section{References}

Armour, K., \& Makopoulou, K. (2005). Evaluation of the National PE and School Sport Professional Development Programme. Interim report (Year 2). Retrieved March 26, 2007:

http://www.lboro.ac.uk/departments/sses/postgraduate/teachertraining/pubs/rep 4 mnths 19-24.pdf

Craig, J. (2004). Shifting boundaries on the professional knowledge landscape: When teacher communications become less safe. Curriculum Inquiry, 34, 395-424.

Darling-Hammond, L \& Bransford, J. (2005).Preparing Teachers for a Changing World: What Teachers Should Learn and Be Able to Do. New York: Jossey-Bass

Day, C et al. (2006). Variations in Teachers' Work, Lives and Effectiveness (VITAE). http://www.dfes.gov.uk/research/data/uploadfiles/RR743.pdf

Day, C. (1999). Developing teachers: The challenge to lifelong learning. London: Falmer Press.

Deglau, D. \& O'Sullivan; M. (2006). The effects of a long-term professional development program on the beliefs and practices of experienced teachers. Journal of Teaching in Physical Education, 25 (4), 379-396

Deglau, D. Ward, P. \& O'Sullivan, M. (2006). Professional dialogue as professional development. Journal of Teaching in Physical Education, 25(4), 413-427.

Franke, M, Carpenter, Levi, L., \& Fennema, E. (2001). Capturing Teachers' Generative Change: A Follow-up Study of Professional Development Mathematics. American Educational Research Journal, 38, 653-689 
Guskey, T. (2003). Professional development and teacher change. Teacher and Teaching: Theory into Practice, 8, 381-391.

ICSSPE/CIEPSS (2005). Magglingen Commitment for Physical Education. 2nd World Summit on Physical Education, Magglingen, Switzerland, Dec 2-5.

Lave, J. \& Wenger, E. (1991). Situated learning: Legitimate peripheral participation. Cambridge, UK: Cambridge University Pres

Little, J. (2002). Locating learning in teachers' communities of practice: Opening up problems of analysis in records of everyday work. Teaching and Teacher Education, 18, 917-946.

Mitchell \& Cubey (2003). Professional Development in Early Childhood Settings. Retrieved March 26, 2007: http://educationcounts.edcentre.govt.nz/research/Bes/index.html McGee, C., Miller, T., \& Patel, S. (2006). Evaluation of Building Capacity in New Zealand Associations. Final Report. Auckland: Ministry of Education and The Royal Society of New Zealand. Retrieved on March 26, 2007:

http://www.penz.org.nz/downloads/SA REPORT\%20AUG06.pdf.

OECD, (2006). OECD Work on Education, 2005-2006. Retrieved on July 14, 2006: http://www.oecd.org/dataoecd/35/40/30470766.pdf.

OECD, (2005). Teachers Matter: Attracting, Developing and Retaining Effective Teachers

- Final Report. Retrieved October 12, 2006: http://www.oecd.org.

Physical Education, School Sport, and Club Links Strategy: Web site: Youth Sport Trust (2006). Retrieved on June 12, 2006: http://www.youthsporttrust.org

Tannehill, D., O'Sullivan, M., \& Ní Chróinín, D. (2006). Developing a Community of Practice in Physical Education. Paper presented at the British Educational Research Association Conference, Warwick, England.

Tinning, R. (2000). Seeking a realistic contribution: Considering physical education within HPE in New Zealand and Australia. Journal of Physical Education New Zealand, 33 (3), 8-22.

Wegner, E. (1998). Communities of Practice as a Social System. Retrieved on September 24, 2006: http://www.co-i-l.com/coil/knowledge-garden/cop/lss.shtml.

Ward, P. \& O'Sullivan, M. (Eds.) (2006). Professional Development in Urban Schools. Journal of Teaching Physical Education Monograph, 25 (4). 